\title{
Gangguan fisiologis wereng batang padi coklat akibat pemberian abu terbang batubara
}

\author{
Physiological disorders of brown planthopper \\ associated with coal fly ash \\ Hafiz Fauzana $^{1 *}$, F.X. Wagiman ${ }^{2}$, Edhi Martono ${ }^{2}$ \\ ${ }^{1}$ Fakultas Pertanian, Universitas Riau \\ Jalan H.R. Soebrantas Km 12, Panam, Riau 28293 \\ ${ }^{2}$ Fakultas Pertanian, Universitas Gadjah Mada \\ Jalan Flora, Bulaksumur, Yogyakarta 55281 \\ (diterima Agustus 2013, disetujui Januari 2014)
}

\begin{abstract}
ABSTRAK
Abu terbang batubara (ATB) dapat dimanfaatkan sebagai agens pengendalian wereng batang padi coklat (WBC) Nilaparvata lugens (Hemiptera: Delphacidae). Kajian ini bertujuan mempelajari gangguan fisiologis WBC yang diberi pemaparan ATB. Pengujian meliputi mortalitas WBC, pengukuran bobot WBC sebelum dan sesudah perlakuan ATB, analisis kadar air WBC, analisis jaringan, dan analisis kimia WBC. Hasil kajian menunjukkan bahwa mortalitas WBC setelah perlakuan sebesar $71 \%$. Gangguan fisiologis ditunjukkan oleh penurunan bobot WBC perlakuan sebesar 67,04\% dan peningkatan bobot WBC kontrol sebesar 6,9\%. Kadar air WBC perlakuan signifikan lebih rendah dibandingkan dengan WBC kontrol. ATB menyebabkan terjadinya pengkerutan jaringan tubuh dan peningkatan kandungan silika dan alumina pada WBC.
\end{abstract}

Kata kunci: abu terbang batubara, aktivitas, gangguan fisiologis, Nilaparvata lugens

\begin{abstract}
Coal fly ash (CFA) can be used as a control agent of brown plant hopper (BPH) Nilaparvata lugens (Hemiptera; Delphacidae). This study was aimed to investigate the physiological disorders in BPH when exposed to CFA. The research was conducted by carrying out tests covering the mortality of BPH, measurement of BPH weight before and after CFA treatment, an analysis of the moisture content in $\mathrm{BPH}$, an analysis of the $\mathrm{BPH}$ tissue, and a chemical analysis of $\mathrm{BPH}$. The results of the study showed that the mortality rate of BPH after treatment was $71 \%$. The physiological disorders due to CFA treatment was indicated by a $67.04 \%$ weight reduction as opposed to a $6.9 \%$ weight increase on the control specimens. The average moisture content of the treated BPH was significantly lower than that of the control specimens. CFA caused a shrinkage of body tissues and an increase in the contents of silica and alumina on BPH.
\end{abstract}

Key words: activity, brown planthopper, coal fly ash, physiological disorders

\footnotetext{
*Penulis korespondensi: Hafiz Fauzana. Fakultas Pertanian Universitas Riau, Kampus Binawidya, Jalan H.R. Soebrantas Km 12, Kecamatan Tampan Panam, Pekanbaru, Riau 28293

Tel: 0761-63270,63271, Faks: 0761-63270,Email: fauzana_hafiz@yahoo.co.id
} 


\section{PENDAHULUAN}

Wereng batang padi coklat (WBC), Nilaparvata lugens Stal, merupakan hama utama tanaman padi dan sering terjadi eksplosi yang menyebabkan gagal panen. Untuk mengendalikan WBC, umumnya petani menggunakan insektisida kimia sintetik yang menyebabkan dampak negatif, yaitu terbentuklah koloni WBC yang resisten dan terbunuhnya musuh alami. Selain itu, insektisida kimia sintetik juga menimbulkan problem lingkungan dan residu pestisida pada bahan makanan sehingga berpengaruh negatif terhadap kesehatan manusia (Miller 2002). Oleh karenanya, teknologi pengendalian hama dengan bahan insektisida yang ramah lingkungan dan ekonomis perlu dikembangkan.

Diantara bahan-bahan insektisida yang bersifat ekonomis dan ramah lingkungan adalah abu terbang (fly ash) (Kiruba et al. 2006). Petani tradisional sering menabur abu dapur pada persemaian padi dan pertanaman kedelai untuk tujuan mengendalikan hama. Pengalaman empiris petani tradisional tersebut belum diteliti sejauhmana efektif. Testimoni oleh petani padi di Bantul, Yogyakarta menyatakan bahwa walang sangit (Leptocorisa acuta (Hemiptera; Alydidae)) terkendali oleh adanya taburan abu vulkanik Gunung Merapi yang meletus pada tahun 2009 (Susamto 2010; komunikasi pribadi).

Kajian aktivitas abu terbang limbah pembakaran kayu pada hama WBC menunjukkan mortalitas $90 \%$ pada dosis tertinggi $\left(12 \mathrm{~g} / \mathrm{m}^{2}\right)$, dengan $\mathrm{LD}_{50}$ sebesar $4,84 \mathrm{~g} / \mathrm{m}^{2}$ atau sebesar 48,4 kg/ha (Wagiman \& Fauzana 2010). Dosis tersebut dipakai untuk kajian efikasi lapangan yang diaplikasi dengan cara dusting juga menunjukkan efektif dan sangat signifikan menurunkan populasi WBC sampai 2 hari setelah aplikasi. Abu terbang batubara (ATB) telah diteliti aktivitasnya pada berbagai serangga hama termasuk Ordo Hemiptera (Narayanasamy 2001).

ATB mempunyai surface area yang tinggi, bersifat pozzolanik dan berfungsi sebagai adsorben. Hal itu terjadi karena ATB berpori dan mempunyai situs aktif yang mempunyai sifat-sifat, seperti elektron dan positive change sehingga dapat mengadsopsi, mempunyai daya ikat terhadap air dan senyawa lainnya. Kandungan $\mathrm{SiO}_{2}$ 28
(54,59\%) dan $\mathrm{Al}_{2} \mathrm{O}_{3}(31,69 \%)$ yang tinggi pada ATB menunjukkan bahwa ATB memungkinkan digunakan sebagai adsorben. Semakin besar kadar kedua komponen dalam ATB, berarti makin banyak situs aktif dari permukaan padatan yang dapat berinteraksi dengan molekul adsorbat sehingga berpengaruh positif terhadap kemampuan adsorpsinya (Rusdiarso 1996; Dahoklory 2009). Kemampuan adsorpsi ATB ini diduga apabila mengenai WBC akan menyebabkan serangga mengalami dehidrasi sehingga terjadi kematian. Aspek yang dipelajari pada kajian ini adalah kinerja ATB dalam membunuh serangga uji.

Kajian ini bertujuan untuk mengetahui dampak fisiologis pemaparan ATB terhadap WBC, yaitu kerusakan jaringan, pengurangan bobot tubuh WBC dan reaksi kimia dari ATB, terutama kandungan silika dan alumina terabsorpsi ke tubuh WBC.

\section{BAHAN DAN METODE}

Penelitian dilaksanakan di Laboratorium Kimia Analitik, Fakultas Matematika dan Ilmu Pengetahuan Alam, Universitas Gadjah Mada (UGM); Laboratorium Pengendalian Hayati, Jurusan Hama dan Penyakit Tumbuhan, Fakultas Pertanian UGM; dan Pusat Studi Pengelolaan Sumber Daya Hayati, UGM. Penelitian ini dimulai dari bulan Maret 2012 sampai Oktober 2012.

\section{Menyiapkan serangga uji}

Serangga uji yang digunakan adalah imago brakhiptera WBC yang umur 2 hari. WBC diambil dari sawah di Yogyakarta kemudian diperbanyak di Pusat Studi Pengelolaan Sumber Daya Hayati, UGM. Bibit padi varietas IR 64 umur seminggu setelah semai digunakan sebagai inang dan WBC dipelihara dalam stoples diameter $19 \mathrm{~cm}$ x tinggi $21 \mathrm{~cm}$ hingga tumbuh dan berkembangbiak sampai mencukupi untuk perlakuan. Regenerasi dilakukan seminggu sekali secara terus menerus selama perbanyakan.

\section{Pengaruh ATB terhadap mortalitas WBC}

ATB yang digunakan berasal dari PT. PLN Pembangkitan Jepara, Jawa Tengah. Pengaruh ATB terhadap mortalitas WBC brakhiptera dikaji 
dengan membandingkan antara mortalitas WBC yang diperlakukan ATB dan kontrol, dengan 5 ulangan. WBC brakhiptera sebanyak 20 ekor dipelihara dalam cup plastik $250 \mathrm{ml}$ yang ditutup kain kasa dengan inang bibit padi varietas IR 64 umur 2 minggu. Pada WBC perlakuan dipapar dengan ATB mengunakan aquarium air pump dengan dosis 0,48 g/cup atau $12 \mathrm{~g} / \mathrm{m}^{2}$ (Wagiman \& Fauzana 2010) Pengamatan mortalitas dilakukan setiap 24 jam sejak perlakuan sampai 72 jam.

\section{Metode pengukuran bobot WBC}

Mortalitas WBC yang disebakan oleh gangguan fisiologis, dianalisis dengan mengukur laju dehidrasi WBC ditunjukkan dengan penurunan bobot tubuh WBC. Metode ini dilakukan dengan menimbang bobot segar satu individu brakhiptera WBC hidup umur 2 hari yang diambil menggunakan aspirator, ditimbang bobot awalnya (A), cara menimbangnya, yaitu seekor WBC dimasukkan dalam kapsul transparan, digunakan timbangan digital kepekaan 0,1 mg. Seekor WBC selanjutnya dipapar dengan ATB untuk WBC perlakuan. Caranya seekor WBC dimasukkan ke dalam gelas plastik diameter $6,5 \mathrm{~cm}$ x tinggi $20 \mathrm{~cm}$. ATB ditimbang sesuai dosis pemaparan, yaitu $12 \mathrm{~g} / \mathrm{m}^{2}$ (Wagiman \& Fauzana 2010), kemudian dipaparkan kedalam gelas plastik yang berisi seekor WBC menggunakan aquarium air pump dan perlengkapannya. WBC terpapar dipindahkan ke cup plastik volume $240 \mathrm{ml}$ (2 cup plastik yang didempetkan, cup bawah diberi air secukupnya, mulut cup ditutup kain kasa untuk mencegah WBC keluar dari arena percobaan). Satu individu WBC yang mati 24 jam (Fauzana 2011) setelah perlakuan dibersihkan dari partikel ATB, lalu ditimbang lagi bobotnya (B). Selisih bobot seekor WBC sebelum dan sesudah perlakuan (C) digunakan untuk ukuran gangguan fisiologisnya. Cara penimbangan yang sama dilakukan terhadap WBC kontrol. Untuk WBC perlakuan dan kontrol masing-masing sebanyak 30 ulangan, yaitu 30 individu WBC kontrol dan 30 individu WBC perlakuan.

\section{Pengukuran kadar air WBC}

Analisis gangguan fisiologis WBC berupa dehidrasi ditunjukkan dengan penurunan kadar air pada WBC terpapar. Ini dibuktikan dengan mengukur kadar air tubuh menggunakan metode gravimetri. Botol kosong ditimbang (A). Botol kosong diisi 300 individu WBC mati terpapar ATB (B), dioven dengan suhu $105{ }^{\circ} \mathrm{C}$ selama 4 jam, kemudian ditimbang (C). Kadar air WBC dihitung dengan persamaan:

$$
\mathrm{KaWBC}=\frac{(\mathrm{B}-\mathrm{C})}{(\mathrm{C}-\mathrm{A})} \times 100 \% \text {, dengan }
$$

KaWBC: kadar air WBC (\%); A: bobot botol kosong (g); B: bobot WBC dan botol (g); C: bobot WBC setelah dioven sampai mencapai bobot konstan dan botol (g).

Pada kontrol 300 individu WBC dimatikan dengan chloroform, selanjutnya metode sama dengan WBC perlakuan. Kriteria gangguan fisiologis ialah jika kadar air tubuh WBC perlakuan secara signifikan lebih rendah daripada kontrol. Pengukuran dilakukan masing-masing 4 ulangan untuk kontrol dan perlakuan.

\section{Analisis jaringan WBC}

Gangguan fisiologis ditandai dengan kerusakan jaringan WBC, dibuktikan dengan pengamatan terhadap imago WBC yang mati akibat terpapar ATB dan kontrol. Pengamatan jaringan difokuskan pada bagian abdomen WBC brakhiptera, yang dianalisis dengan transmission electron microscopy (TEM) perbesaran 3000 kali. Prosedur pertama dilakukan preparasi sampel, meliputi tahap fixative, dehydrate (pencucian), proses resinasi (memberi resin), dan tahap ultra thin sectioning (pengirisan tipis) dengan ultra microtom merek Leica EM UC7-NT. Kedua dilakukan pengukuran dengan TEM merek Jeol JEM-1400. Langkah pelaksanaannya sampel diletakan ke grid, dimasukan grid ke holder, di vacuum pada column. Setelah vacuum mencapai \pm 29 uA baru holder dimasukan dan divacuum sampai mencapai 25-27 uA. Spesimen imago WBC dilihat dengan mengatur control panel agar sampel terlihat pas posisi ditengah, focus, baru di foto. Imago WBC yang diamati, yaitu 10 individu WBC kontrol dan 10 individu WBC perlakuan.

\section{Analisis kimia WBC}

ATB mengandung senyawa silika dan alumina mencapai 86,28\% (Rusdiarso 1996), kedua senyawa tersebut bersifat absorben yang 
dapat menyerap air dan senyawa polar dari serangga (Ulrich et al. 2009) sehingga diprediksi menimbulkan gangguan fisiologis jaringan WBC. Terserapnya kedua senyawa dalam tubuh WBC, dianalisis menggunakan metode destruksi dan diukur dengan atomic absorption spectrophotometer (AAS). Analisis membutuhkan serangga sampel $\pm 0,05 \mathrm{~g}$ WBC $( \pm 500$ individu imago WBC). Analisis dilakukan terhadap WBC perlakuan dan kontrol. Sebelum dianalisis WBC yang mati karena terpapar ATB dibersihkan tubuhnya dari partikel ATB.

\section{HASIL}

\section{Pengaruh ATB terhadap mortalitas, bobot dan} kadar air WBC

Aktivitas ATB pada WBC menunjukkan sifat insektisidal. Mortalitas brakhiptera WBC yang diperlakukan dengan ATB mencapai $71 \%$ pada 72 jam setelah pemaparan, sedangkan kontrol tidak ada kematian WBC (Tabel 1).

Hasil pengukuran bobot seekor brakhiptera WBC sebelum dan setelah 24 jam terpapar ATB sebanyak 30 ulangan didapat bahwa rerata bobot satu individu imago WBC, yaitu 2,1 mg sebelum dan menjadi 0,6 mg setelah terpapar ATB, dimana terjadi penurunan bobot sebesar rata-rata $67,04 \%$. Pada WBC kontrol terjadi peningkatan bobot rerata $6,9 \%$, yaitu dari rerata $2,2 \mathrm{mg}$ menjadi 2,4 $\mathrm{mg}$ (Tabel 2).

Hasil pengukuran kadar air imago WBC setelah pemaparan ATB signifikan berbeda nyata dengan kontrol (Tabel 3). Kadar air WBC yang diberi pemaparan ATB ternyata sangat rendah, yaitu rerata 4,81\%, sementara WBC kontrol sangat tinggi, yaitu rerata 64,94\% (Tabel 3).

\section{Pengaruh ATB terhadap jaringan abdomen WBC}

Hasil pengamatan terhadap jaringan pada bagian abdomen imago brakhiptera WBC dianalisis dengan TEM, menunjukkan jaringan WBC yang dipaparkan ATB mengalami pengerutan sel dibanding jaringan WBC tanpa pemaparan ATB (Gambar 1 dan 2).

Jaringan pada bagian abdomen imago WBC yang tidak terpapar ATB terlihat jelas bagianbagiannya dimana terdapat vesikel, kromatin, vakuola, lumen, sitoplasma, dan lainnya (Bambang 2014; komunikasi pribadi), tetapi pada jaringan WBC yang terpapar ATB terlihat sudah rusak, mengkerut dimana bagian-bagian dari jaringan

Tabel 1. Mortalitas brakhiptera wereng batang coklat (WBC) pada kontrol dan perlakuan abu terbang batubara

\begin{tabular}{|c|c|c|c|c|c|c|}
\hline \multirow{3}{*}{ Ulangan } & \multicolumn{6}{|c|}{ Mortalitas brakhiptera WBC (\%) } \\
\hline & \multicolumn{2}{|c|}{24 jam } & \multicolumn{2}{|c|}{48 jam } & \multicolumn{2}{|c|}{72 jam } \\
\hline & Perlakuan & Kontrol & Perlakuan & Kontrol & Perlakuan & Kontrol \\
\hline 1 & 65 & 0 & 70 & 0 & 70 & 0 \\
\hline 2 & 60 & 0 & 70 & 0 & 80 & 0 \\
\hline 3 & 60 & 0 & 60 & 0 & 60 & 0 \\
\hline 4 & 55 & 0 & 55 & 0 & 55 & 0 \\
\hline 5 & 90 & 0 & 90 & 0 & 90 & 0 \\
\hline Rerata & 65,00 & 0 & 69,00 & 0 & 71,00 & 0 \\
\hline SD & 10,48 & & 12,00 & & 12,80 & \\
\hline $\mathrm{CV}$ & 16,13 & & 17,39 & & 18,03 & \\
\hline
\end{tabular}

SD: standard deviation; $\mathrm{CV}$ : coefficint of variation

Tabel 2. Bobot awal dan akhir imago wereng batang coklat 24 jam setelah pemaparan abu terbang batubara (30 ulangan)

\begin{tabular}{|c|c|c|c|c|c|c|c|c|}
\hline \multirow{3}{*}{ Statistik } & \multirow{2}{*}{\multicolumn{2}{|c|}{ Bobot awal (g) }} & \multirow{2}{*}{\multicolumn{2}{|c|}{ Bobot akhir (g) }} & \multicolumn{4}{|c|}{ Selisih bobot } \\
\hline & & & & & \multicolumn{2}{|c|}{$\mathrm{g}$} & \multicolumn{2}{|c|}{$\%$} \\
\hline & Perlakuan & Kontrol & Perlakuan & Kontrol & Perlakuan & Kontrol & Perlakuan & Kontrol \\
\hline Rerata & 0,0021 & 0,0022 & 0,0006 & 0,0024 & 0,0014 & 0,00016 & 67,0404 & 6,900 \\
\hline SD & 0,0005 & 0,0004 & 0,0001 & 0,0003 & 0,0005 & 0,00028 & 12,5361 & 15,777 \\
\hline $\mathrm{CV}$ & 26,9467 & 19,2107 & 27,2868 & 14,3469 & 40,4394 & 181,8430 & 18,6994 & 228,635 \\
\hline
\end{tabular}

SD: standard deviation; CV: coefficint of variation 


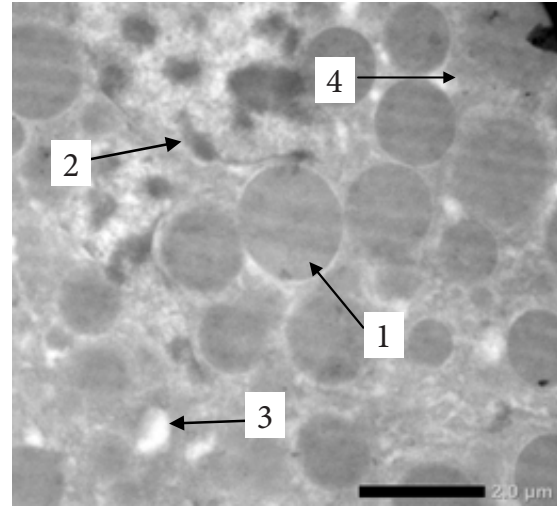

a

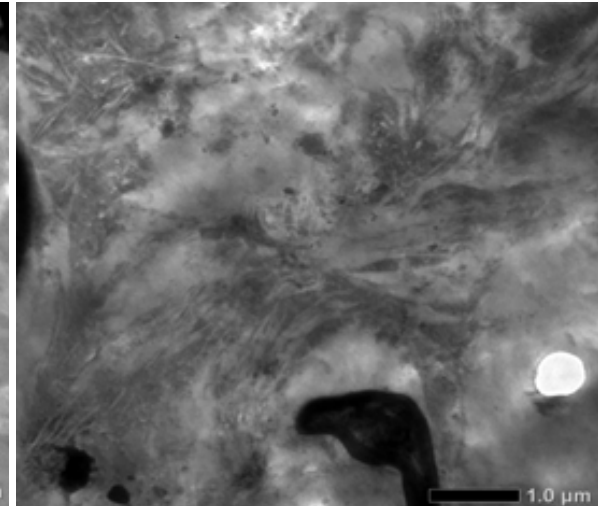

$\mathrm{b}$

Gambar 1. Penampang melintang jaringan bagian abdomen brakiptera wereng batang coklat kontrol (a) dan terpapar abu terbang batubara (b). 1: vesikel; 2: kromatin; 3 vakuola; 4: sitoplasma. (TEM perbesaran $3000 \mathrm{X})$.

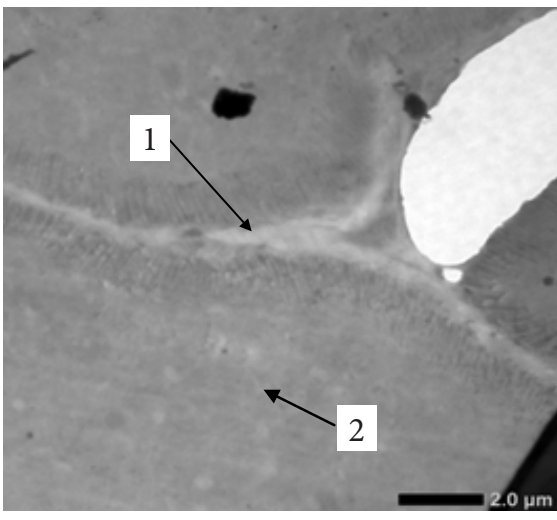

a

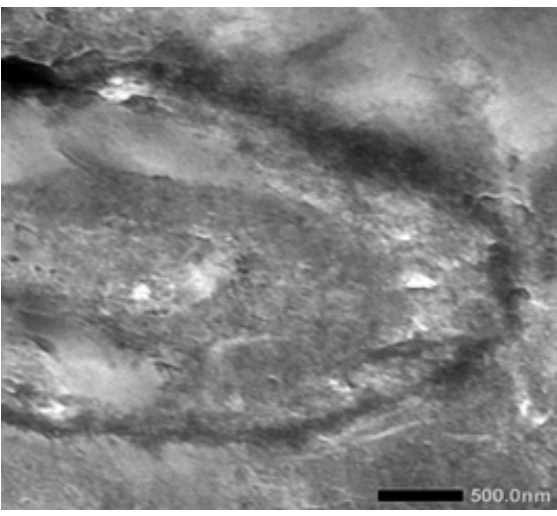

b

Gambar 2. Penampang membujur jaringan saluran pencernaan imago wereng batang coklat kontrol (a) dan terpapar abu terbang batubara (b). 1: lumen; 2: sitoplasma. (TEM perbesaran $2000 \mathrm{X}$ dan $8000 \mathrm{X}$ ).

Tabel 3. Kadar air imago wereng batang coklat (WBC) terpapar abu terbang batubara dan wereng batang coklat kontrol

\begin{tabular}{lcc}
\hline \multirow{2}{*}{ Ulangan } & \multicolumn{2}{c}{ Kadar air WBC (\%) } \\
\cline { 2 - 3 } & WBC perlakuan & WBC kontrol \\
\hline 1 & 2,40 & 60,37 \\
2 & 2,13 & 59,60 \\
3 & 6,10 & 68,00 \\
4 & 8,61 & 71,78 \\
\hline Rerata & 4,81 & 64,94 \\
\hline SD & 3,11 & 5,93 \\
\hline
\end{tabular}

tidak terlihat jelas lagi sehingga tidak dapat lagi dianalisis secara struktural. Jaringan pada saluran pencernaan imago WBC yang tidak terpapar ATB juga terlihat lengkap dimana terdapat lumen, sitoplasma, dan lainnya, sementara pada jaringan WBC yang terpapar ATB terlihat selnya sudah rusak, terjadi pengkerutan sel (Gambar 2).

\section{Pengaruh ATB terhadap kandungan silika dan alumina WBC}

Hasil analisis kandungan silika dan alumina pada tubuh imago yang terpapar ATB signifikan berbeda nyata dibanding kontrol. Kandungan senyawa silika pada WBC terpapar ATB lebih tinggi yaitu rerata $2,35 \%$ dibanding WBC pada kontrol yaitu rerata $1,33 \%$. Begitupun kandungan senyawa alumina pada WBC terpapar ATB lebih tinggi yaitu rerata $0,80 \%$ dibanding WBC kontrol yaitu rerata $0,15 \%$ (Tabel 4 ).

\section{PEMBAHASAN}

ATB bersifat insektisidal terhadap WBC. Aktivitas ATB menyebabkan mortalitas nimfa WBC dan imago. Stadia nimfa WBC lebih cepat mati oleh pemaparan ATB dibanding stadia imago (Fauzana 2011). ATB dihembuskan ke tanaman 
Tabel 4. Kandungan silika dan alumina pada imago wereng batang coklat (WBC) dengan perlakuan abu terbang batubara

\begin{tabular}{lccccc}
\hline \multirow{2}{*}{ Ulangan } & \multicolumn{2}{c}{$\begin{array}{c}\text { Silika pada WBC } \\
(\%)\end{array}$} & & \multicolumn{2}{c}{$\begin{array}{c}\text { Alumina } \\
\text { pada }\end{array}$} \\
\cline { 2 - 3 } \cline { 5 - 6 } & Perlakuan & Kontrol & & Perlakuan & Kontrol \\
\hline 1 & 1,5114 & 2,3380 & & 0,0297 & 0,8122 \\
2 & 1,5356 & 2,3583 & & 0,0304 & 0,8075 \\
3 & 1,4872 & 2,3785 & & 0,0304 & 0,8169 \\
4 & 1,1749 & 2,3385 & & 0,1007 & 0,8137 \\
5 & 1,1225 & 2,3556 & & 0,3653 & 0,7978 \\
6 & 1,1487 & 2,3556 & & 0,3756 & 0,8057 \\
\hline Rerata & 1,3305 & 2,3540 & 0,1553 & 0,8089 \\
\hline SD & 0,1999 & 0,0149 & 0,1688 & 0,0068 \\
\hline CV & 15,0321 & 0,6357 & 108,7041 & 0,8444 \\
\hline
\end{tabular}

Nilai P (Uji t $\alpha 0,05) \quad 0,00005 \quad 0,00025$

SD: standard deviation; CV: coefficint of variation

padi merupakan racun lambung terhadap serangga penggigit pengunyah. ATB menyebabkan kerusakan mandibel. Partikel ATB yang termakan mengganggu saluran pencernaan larva serangga sehingga menimbulkan kematian (Narayanasamy 1994). Bagaimana ATB membunuh WBC belum diketahui dan menjadi alasan utama kajian ini.

Penurunan bobot WBC yang mencapai ratarata $67,04 \%$ mengindikasikan bahwa WBC mengalami gangguan fisiologis berupa dehidrasi akibat pemaparan ATB. Hasil pengukuran kadar air WBC yang terpapar ATB dan kontrol mendukung hasil penimbangan bahwa WBC memang mengalami gangguan fisiologis, yaitu dehidrasi dengan pemaparan ATB. Dehidrasi menyebabkan terjadinya gangguan keseimbangan air tubuh. Air komponen essensial yang berfungsi sebagai medium dimana seluruh reaksi kimia (metabolisme) berlangsung. Media melarutkan makanan dan diangkut keseluruh tubuh. Dehidrasi menyebabkan terhambatnya metabolisme tubuh, dan pada tahap berikutnya dapat menimbulkan kematian (Beckett 1986).

ATB berfungsi sebagai adsorben. Oleh karena itu, serangga yang diperlakukan dengan ATB akan mengalami gangguan air tubuh dan zat lilin pada epikutikula serangga. Partikel ATB yang berinteraksi dengan kutikula akan menyerap senyawa polar pada kutikula serangga dan abu terserap dalam kutikula (Ulrichs et al. 2009).

Menurut Kumar et al. (2005) dan Dahoklory (2009) ATB bersifat pozzolanik berarti dapat bereaksi dengan kapur dan dengan media air membentuk senyawa yang bersifat mengikat. Sifat ini ditentukan dengan adanya kandungan berbagai senyawa kimia yang biasa terdapat dalam bahan pozzolan yang juga dalam jumlah besar terdapat pada $\mathrm{ATB}$, yaitu $\mathrm{SiO}_{2}, \mathrm{Al}_{2} \mathrm{O}_{3}$, dan $\mathrm{Fe}_{2} \mathrm{O}_{3}$. Dengan demikian apabila ATB dipaparkan pada WBC, senyawa-senyawa pozzolan dalam ATB akan mengikat air yang terdapat pada tubuh WBC. Pada akhirnya mengakibatkan WBC dehidrasi, zat elektrolit dan metabolisme terhambat, pada tingkat dehidrasi bobot serangga mengalami kematian.

Kadar air tubuh serangga bervariasi dari kirakira 50-90\% bobot tubuh, pengurangan kadar air dapat menyebabkan kematian, misalnya hama Rhodnius sp. dan Tenebrio sp. mati bila kadar airnya turun dari kira-kira 75 sampai $60 \%$. Hal ini terjadi karena defisit kelembaban yang permeabel. Serangga tidak bisa mengatasi laju kehilangan air, sehingga terjadi gangguan metabolisme tubuh, dan selanjutnya serangga akan mati (Chapman 1982).

ATB apabila dipaparkan terhadap imago WBC menyebabkan jaringan hancur dan mengkerut. Terjadinya pengkerutan pada jaringan WBC adalah implikasi dari peristiwa plasmolisis dalam sel WBC, yaitu terjadinya peristiwa osmosis di mana cairan yang ada didalam sel keluar dari sel akibat sel berada pada lingkungan yang bersifat hipertonis, sehingga tekanan sel terus berkurang. Karena kadar air dalam sel menurun drastis, sel akan mengalami pengkerutan (krenasi) (Ling 2007; Mader \& Windelspecht 2011).

Terjadinya peningkatan kandungan silika dan alumina pada WBC yang terpapar ATB, menunjukkan bahwa silika dan alumina yang tinggi pada ATB, yaitu 83,55\% (Fauzana 2013; unpublished) meresap ke dalam tubuh WBC. Sifat senyawa yang ada pada ATB, yaitu silika dan alumina yang bersifat sebagai absorben, menyebabkan gangguan fisiologis pada WBC, yaitu terjadi dehidrasi yang ditunjukkan oleh penurunan bobot tubuh, kadar air dan kerusakan jaringan.

Kadar $\mathrm{SiO}_{2}$ dan $\mathrm{Al}_{2} \mathrm{O}_{3}$ yang tinggi menentukan kekuatan adsorben. Semakin tinggi kadar kedua senyawa tersebut dalam ATB semakin banyak situs aktif dari permukaan partikel ATB yang dapat berinteraksi dengan molekul adsorbat sehingga semakin kuat kemampuan absorpsinya (Rusdiarso 
1996). Dengan demikian kemampuan absorbsi dari senyawa silika dan alumina dalam ATB yang terpapar ke tubuh WBC menyebabkan gangguan fisiologis terhadap WBC. Hal ini ditunjukkan oleh terjadinya dehidrasi dan kerusakan jaringan sehingga menimbulkan kematian WBC.

\section{KESIMPULAN}

Hasil pengujian menyimpulkan bahwa telah terjadi gangguan fisiologis terhadap imago WBC yang dipapar ATB yang ditunjukkan oleh penurunan bobot $67,04 \%$ WBC perlakuan dan peningkatan bobot $6,9 \%$ WBC kontrol. Kadar air WBC perlakuan rendah, yaitu rerata $4,81 \%$ sementara WBC kontrol rerata 64,94\%. Terjadi pengkerutan jaringan pada bagian abdomen imago WBC yang terpapar ATB.

\section{UCAPAN TERIMA KASIH}

Terima kasih penulis kepada Direktorat Jenderal Pendidikan Tinggi yang telah memberikan dana hibah Doktor tahun 2013 melalui Lembaga Penelitian Universitas Riau untuk mahasiswa program Doktor.

\section{DAFTAR PUSTAKA}

Beckett BS. 1986. Biology A. Modern Introduction. GCSE edition. New York: Oxford University Press.

Chapman RF. 1982. The Insects Structure and Function. $3^{\text {th }}$ Edition. Cambridge, Massachusetts: Harvard University Press.

Dahoklory JD. 2009. Rekayasa Pemanfaatan Abu terbang Sebagai Bahan Baku Pembuatan Batako (Studi kasus Pembangkit Listrik Tenaga Uap Kupang Propinsi Nusa Tenggara Timur). Master Thesis. Yogyakarta: Universitas Gadjah Mada.

Fauzana H. 2011. Kajian Potensi Abu Terbang (fly ash) dari Batubara untuk Mengendalikan Hama Wereng Batang Padi Cokelat (Nilaparvata lugens Stal.). Riau: Laporan Penelitian DIPA Universitas Riau Tahun Anggaran 2011.
Fauzana H. 2013. Mekanisme Limbah Abu Terbang Batubara Membunuh Hama Wereng Batang Padi Coklat (Nilaparvata lugens). PhD Thesis. Riau: Universitas Riau.

Kiruba S, Mishra BP, Stalin ST, Jeeva S, Dhas SSM. 2006. Traditional pest management practices in Kanyakumari distict, Southern Peninsular India. Indian Journal of Traditional Knowledge 5:7174.

Kumar V, Singh G, Rai R. 2005. Fly ash: A material for an other green revolution. New Delhi: Fly ash utilization Programme (FAUP), TIFAC, DST.

Ling G. 2007. History of the membrane (Pump) theory of the living cell from its beginning in mid- $19^{\text {th }}$ century to its disproof 45 years ago - though still taught worldwide today as established truth. Physicological Chemistry and Physics and Medical NMR 39:1-67.

Mader SS, Windelspecht M. 2011. Essentials of biology. $2^{\text {sd }}$ edition. New York: McGraw-Hill Publishing Company.

Narayanasamy P. 1994. Studies on the utility of lignite fly ash as an insecticide and an adjuvant in insecticide formulations. Final Project Report. Chennai: Tamil Nadu State Council for Science and Technology.

Narayanasamy P. 2001. Indigenous pest suppression. In: Upadhyay RK, Mukerji KG, Chamola BP (Eds.). Biocontrol Potential and its Exploitation in Sustainable Agriculture. Volume 2. Insect Pest. pp. 87-111. New York: Kluwer Academic/ Plenum Publishers.

Rusdiarso B. 1996. Laporan Penelitian Analisis dan Kajian Tentang Pemanfaatan Abu Layang Sebagai Adsorben Zat Warna. Yogyakarta: Universitas Gadjah Mada.

Ulrichs C, Schmidt U, Pelzer TM, Goswami A, Mewis I. 2009. Hard coal fly ash and silica effect of fine particulate matter deposits on Brassica chinensis. American Journal of Agricultural and Biological Sciences. 4:24-31. doi: http://dx.doi. org/10.3844/ajabssp.2009.24.31.

Wagiman FX, Fauzana H. 2010. Toksisitas Abu Terbang terhadap Nilaparvata lugens dan Kompleks Predatornya. Laporan Akhir Hibah Penelitian Fakultas Pertanian Tahun Anggaran 2010. Yogyakarta: Universitas Gadjah Mada.

Miller GT. 2002. Living in the environment, principles, connections and solutions. Journal Biologia Plantarum. 45:128. doi: http://dx.doi. org/10.1023/A:1015199330106. 